\title{
Effect of Some Treatments of Bio and Organic Fertilization on Vegetative Growth of Moringa Olifera Plant
}

\author{
Abo El-Ghait, E. M., Youssef, A.S.M. and Kashlan, O. \\ Hort. Department, Faculty of Agriculture, Benha University, EGYPT \\ Corresponding Author: ahmed.youssef@fagr.bu.edu.eg
}

\begin{abstract}
Two field experiments were carried out at the Experimental Farm and in the Laboratory of Horticulture Department Faculty of Agriculture at Moshtohor, Benha Univ., during 2015/2016 and 2016/2017 seasons to study the effect of some fertilizer treatments (organic and bio-fertilizers as well as their combination ) on vegetative growth and some chemical constituents of Moringa olifera plants. The treatments of bio-fertilizer were as follow: Control: without bio fertilizer treatments, One dose i.e., added during seed sowing, Two doses i.e., the first during seed sowing and the second after the first cut., Three doses i.e., the first during seed sowing, whereas the second after the first cut while the third one was added after the second cut. Whereas, the treatments of bio fertilizer were compost containing plant sources and cattle manure at the rate of $0.0,5,10$ and $15 \mathrm{~m}^{3} / \mathrm{fed}$., was thoroughly mixed with the soil before planting. The obtained results showed that. The heaviest fresh and dry weights of moringa herb / plant were gained by 15 ton compost/fed.-fertilized plants, followed by 10 ton compost/fed.-fertilized plants in the two seasons. Also, using the treatment of three doses showed to be the most effective one for inducing the highest fresh weight of herb, followed by the treatment of two doses in the two seasons. The combination of bio fertilizer at the high dose significantly induced the greatest values of plant height, particularly those treated with organic fertilizer at the highest concentration in the two seasons. The greatest values of branches and leaves number / plant were gained by the combinations of organic and bio fertilizers at the medium and high levels in the two seasons.
\end{abstract}

Key words: Moringa olifera, bio and organic fertilizers and vegetative growth

\section{Introduction}

Moringa oleifera Lamarck is a species of the monogeneric family Moringaceae (order: Brassicales), that includes 13 species of trees and shrubs (Fahey, 2005). M. oleifera is indigenous to Northwest India (Ramachandran et al., 1980) but, at present it is widely distributed in the tropics throughout the Pacific region (Aregheore, 2002), West Africa (Freiberger et al., 1998; Lockett et al., 2000), as well as Central America and the Caribbean (Ramachandran et al., 1980; Foidl et al., 1999). It is a typical multipurpose tree of significant economic importance because of its several industrial and medicinal applications and various products to be used as food and feed which can be derived from its leaves and fruits (Ramachandran et al., 1980).

Leaves of Moringa represent an important source of nutrients for rural populations (Gupta et al., 1989; Lockett et al., 2000). Most reports indicate that Moringa leaves are rich in protein and present an amino acid composition, which is suitable for human and animal nutrition (Gupta et al., 1989; Makkar and Becker, 1996; Freiberger et al., 1998). Fahey (2005), referred to Moringa as a nutrient dense food source because of its high nutritional value of leaves, pods and seeds. $100 \mathrm{~g}$ one hundred of Moringa leaves contain four times more vitamin A than the same quantity of carrots, four times of calcium in a cup of milk, iron more than $100 \mathrm{~g}$ of spinach, seven times of vitamin $\mathrm{C}$ in $100 \mathrm{~g}$ of oranges and three times of potassium in $100 \mathrm{~g}$ of bananas.

The protein quality of Moringa leaves also rivals that of milk and eggs (Fahey, 2005). The results in Sreelatha and Padm (2009) show that the antioxidants vary with the stage of maturity in Moringa oleifera leaves (number of cuts). Zimmermann and Zentgraf (2005) have reported that the components of both the enzymatic and the non-enzymatic antioxidant system correlate well with oxidative stress during senescence and plant development Also, polyphenols are responsible for the antioxidant activity, the obtained amount of total polyphenols in the extract indicated the extract that it possess a high antioxidant activity (Sreelatha and Padm 2009).

Moyo et al., 2011 reported that, the decrease of condensed tannins after drying may be due to decomplexation between tannins and proteins and depolymerisation and oxidation of tannins. The content of total phenols $(2.02 \%)$ in this study was lower than previously reported. This plant has been well documented for its medicinal importance for a long time (Abdulkarim et al., 2005). High biomass productions of Moringa of over $100 \mathrm{t}$ of dry matter/ha can be achieved under intensive farming conditions (Foidl et al., 1999) and in the last decade large-scale cultivation has been initiated (Makkar and Becker, 1996). Therefore, there is a need to make proper methods to enhance Moringa cultivation in Egypt, and to enhance its nutritional quality to be 
used for different purposes.Recently, unconventional efforts are used to minimize the amounts of chemical fertilizers which applied to medicinal and aromatic plants in order to reduce production cost and environmental pollution without reduction of yield. Therefore, the trend now is using the bio and organic fertilizers. Bio-fertilizers are reasonably safer to the environment than chemical fertilizers and play an important role in decreasing the use of chemical fertilizers. Consequently, it causes a reduction in environmental pollution. Bio fertilizers are microbial inoculants consisting of living cells of microorganism like bacteria, algae and fungi alone or combination which may help in increasing crop productivity. Bio fertilizers can influence plant growth directly through the production of phytohormones such as gibberellins, cytokinins and IAA that act as growth regulators and indirectly through nitrogen fixation and production of biocontrol agents against soil-borne phytopathogens and consequently increase formation of metabolites which encourage the plant vegetative growth and enhance the meristematic activity of tissues to produce more growth (Glick, 2003 and Ahmed and Kibret, 2014). The effect of bio-fertilizers on vegetative growth, yield and oil productivity in several studied was revealed by Badran and Safwat (2004) on fennel. Ismail (2007) on dragonhead plants, Amran (2013) on Pelargonium graveolens plants and El-Khyat (2013) on Rosmarinus officinalis. Organic fertilizers are obtained from animal sources such as animal manure or plant sources like green manure. Continuous usage of inorganic fertilizer affects soil structure. Hence, organic manures can serve as alternative to mineral fertilizers for improving soil structure (Shahram and Ordookhani, 2011) and microbial biomass (Suresh et al. 2004). The addition of organic fertilizers to agricultural soils has beneficial effects on crop development and yields by improving soil physical and biological properties (Zheljazkov and Warman, 2004). Organic and bio fertilizers in comparison of the chemical fertilizers have lower nutrient content and are slow release but they are as effective as chemical fertilizers over longer periods of use (Naguib, 2011 and Mohamed et al., 2012). In this respect, Amran (2013) show that organic fertilizers enhanced vegetative growth parameters and essential oil productivity of Pelargonium graveolens. The aim of this study was therefore to determine the effect of three doses of bio-fertilizer and three levels of organic fertilizer on growth, yield and active ingredients of moringa plant.

\section{Materials and Methods}

Two field experiments were carried out at the Experimental Farm and in the Laboratory of Horticulture Department Faculty of Agriculture at Moshtohor, Benha Univ., during 2015/2016 and $2016 / 2017$ seasons to study the effect of some fertilizer treatments (organic and bio-fertilizers as well as their combination ) on vegetative growth and some chemical constituents of Moringa olifera plants. Moringa olifera seeds were obtained from Floriculture Farm, Horticulture Department, Faculty of Agriculture, Benha Univ. Seeds were sown in clay loam soils on $15^{\text {th }}$ October in both seasons in plots $(1 \times 1 \mathrm{~m})$ containing two rows $(50 \mathrm{~cm}$. in between) every row contains two hills $(50 \mathrm{~cm}$. apart) and 45 days later, the plants were thinned, leaving only one seedling/hill.

Physical and chemical characters of the used soil are shown in Tables (a) and (b), Physical analysis was estimated according to Jackson (1973) whereas, chemical analysis was determined according to Black et al. (1982).

Table (a): Physical analysis of the experimental soil:

\begin{tabular}{|c|c|c|c|}
\hline \multirow{2}{*}{ Parameters } & \multirow{2}{*}{ Unit } & \multicolumn{2}{|c|}{ Seasons } \\
\hline & & $2016 / 2017$ & $2017 / 2018$ \\
\hline Coarse sand & $\%$ & 4.28 & 4.62 \\
\hline Fine sand & $\%$ & 16.78 & 16.63 \\
\hline Silt & $\%$ & 26.27 & 27.42 \\
\hline Clay & $\%$ & 52.67 & 51.33 \\
\hline Textural class & ------ & Clay loam & Clay loam \\
\hline
\end{tabular}

Table (b): Chemical analysis of the experimental soil.

\begin{tabular}{|c|c|c|c|}
\hline \multirow{2}{*}{ Parameters } & \multirow{2}{*}{ unit } & \multicolumn{2}{|c|}{ seasons } \\
\hline & & $2011 / 2012$ & $2012 / 2013$ \\
\hline $\mathrm{CaCo}_{3}$ & $\%$ & 0.93 & 1.01 \\
\hline Organic matter & $\%$ & 2.09 & 2.11 \\
\hline Available nitrogen & $\%$ & 0.31 & 0.93 \\
\hline Available phosphorus & $\%$ & 0.12 & 0.36 \\
\hline Available potassium & $\%$ & 0.24 & 0.79 \\
\hline E.C & $\mathrm{dS} . \mathrm{m}^{-1}$ & 0.91 & 0.86 \\
\hline $\mathrm{pH}$ & ---------- & 7.58 & 7.61 \\
\hline
\end{tabular}


Bio-fertilizer treatment:

Moringa olifera seeds were inoculated with a mixture of nitrobein + phosphorein contained efficient strains of nitrogen fixing bacteria namely, Azotobacter chroococcum + phosphate dissolving bacteria (Bacillus megaterium var phosphaticum) which supplied by the Department of Microbiology, Agric. Res. Center, Giza was used in this study as biological activators. The strains were characterized by a good ability to infect its specific host plant and by its high efficiency in $\mathrm{N}$-fixation and phosphate solublizing. Seeds of dragonhead plants were washed with water and air-dried, thereafter the seeds were soaked in cell suspension of the mixture of nitrobein and phosphorein ( $1 \mathrm{ml}$ contains $10^{8}$ viable cell) for 30 min. Gum arabic (16\%) was added as an adhesive agent prior to soaking. The inoculated seeds were air dried at room temperature for one hour before sowing. Another two applications were applied $(2 \mathrm{~kg} / \mathrm{fed})$ as an aqueous solution, the first one was applied just before irrigation after the first cut, whereas the second one was done after the second cut in the two seasons. Therefore, the treatments of biofertilizer were as follow:

1- Control: without bio fertilizer treatments

2- One dose i.e., added during seed sowing

3- Two doses i.e., the first during seed sowing and the second after the first cut.

4- Three doses i.e., the first during seed sowing, whereas the second after the first cut while the third one was added after the second cut.

\section{Organic fertilizer treatment:}

Organic fertilizer i.e. compost containing plant sources and cattle manure at the rate of $0.0,5,10$ and $15 \mathrm{~m}^{3} / \mathrm{fed}$., was thoroughly mixed with the soil before planting, the chemical properties of the tested compost are presented in Table (c).

Table (c): Chemical properties of the used compost:

\begin{tabular}{|c|c|c|c|c|c|c|c|c|c|}
\hline Parameters & $\begin{array}{c}\text { Ec } \\
\text { dS.m-1 } \\
(\mathbf{1 : 5 )}\end{array}$ & $\begin{array}{c}\text { pH } \\
(\mathbf{1 : 5})\end{array}$ & $\begin{array}{c}\text { Total } \\
\text { C \% }\end{array}$ & $\begin{array}{c}\text { Total } \\
\text { N \% }\end{array}$ & $\begin{array}{l}\text { Total } \\
\text { P \% }\end{array}$ & $\begin{array}{l}\text { Total } \\
\text { K \% }\end{array}$ & $\begin{array}{c}\text { Total } \\
\text { Fe } \\
\text { (ppm) }\end{array}$ & $\begin{array}{c}\text { Total } \\
\text { Zn } \\
(\mathbf{p p m})\end{array}$ & $\begin{array}{l}\mathrm{C}: \mathrm{N} \\
\text { ratio }\end{array}$ \\
\hline Reading & 2.32 & 6.81 & 23.29 & 1.16 & 0.64 & 1.59 & 1347 & 384 & $20: 1$ \\
\hline
\end{tabular}

Experiment layout:

The design of this experiment was factorial experiments in a complete randomize block design with 16 treatments represented the combinations between bio-fertilizer at the rates of 0 , one, two and three doses and organic fertilizer at the rates of 0,5 , 10 and $15 \mathrm{~m} 3 / \mathrm{fed}$. (4 bio fertilization levels $\mathrm{x} 4$ organic fertilizer levels) replicated three times (each replicate consisted of five beds. Common agricultural practices (irrigation, manual weed control,... etc.) were carried out when needed.

\section{Sampling and collecting data:}

Three cuts in intervals at mid-July, first September and mid-October for both studied seasons were harvested by picking the top four leaves of plants leaving the apical leaf in place. (Goss , 2012). At each cut, the following parameters were measured :-

I. Vegetative growth parameters:-

Average plant height $(\mathrm{cm})$, Number of lateral branches / plant, Number of leaves / plant, Stem diameter (mm), Fresh weight (g/plant), Dry weight(g/plant), Total yield (g/plant), Estimated yield (Ton/ fed)

\section{Mineral constituents :-}

Leaves of both Moringa species and for each cut were oven dried at $60^{\circ} \mathrm{C}$ to obtain the constant weight and ground to pass through a 2-mm sieve. The samples were digested using concentrated HNO3 and HOCl4 (2:1), following the procedure adapted by Rashid (1986).
The determination of macro elements was done as follow :-

1. Total $\mathrm{N}$ as $\mathrm{g} / 100 \mathrm{~g}$ dry weight was determined by the semi-micro Kjeldahl procedure (Kass and Rodri'guez 1993) The presence of $P$ content as g/ $100 \mathrm{~g}$ dry weight was recorded in a UVspectrophotometer (UV-4000, O.R.I. Germany) at $410 \mathrm{~nm}$. Color was developed with ammonium molybdate and ammonium vandate solutions

2. A flame photometer (Jenway PEP-7) was used to determine $\mathrm{K}$ content as g/ $100 \mathrm{~g}$ dry weight in diluted extracts of plant material by using a $\mathrm{K}$ filter (Chapman and Pratt 1961).

\section{Determination of Active ingredients}

\section{Total Chlorophyll}

Total chlorophyll in moringa leaves were determined after every harvest except the uniformity cut using the protocol devised by Nagata and Yamashta (1992). Total carotenoids (mg/100g fresh weight).

-Total carotenoids were determined as $\mathrm{mg} / 100 \mathrm{~g}$ fresh weight) by using colorimetric method according to (A.O.A.C.1990)

3. Total flavonoid content (mg/g fresh weight) :

Total flavonoid content of the samples was measured using a colorimetric method (Zhishen et al., 1999; Dewanto et al., 2002).

4.Total tannins (mg/100g dry weight):

Total tannins were determined in herb by using Folin Denis colorimetric method (A.O.A.C.1990) .

5. Ascorbic acid content (mg/100g fresh weight): 
The L-ascorbic acid content (V.C) was determined according to the methods by (A.O.A.C.1990)

\section{Statistical analysis:}

The obtained data in both seasons of study were subjected to analysis of variance as a factorial experiment in RCBD. L.S.D. method was used to differentiate between means according to Snedecor and Cochran (1989).

\section{Results and Discussion}

Effect of bio and organic fertilizer as well as their combination on growth and chemical composition of Moringa olifera plants:

\section{Herb fresh weight/plant}

Data presented in Table (1) reveal that all tested concentrations of organic fertilizer statistically increased herb fresh weight of Moringa olifera plants of as compared with un-fertilized plants in both seasons. However, the heaviest fresh weight of moringa herb was gained by 15 ton compost/fed.fertilized plants as it gave 113 and $151.2 \mathrm{~g}$, followed by 10 ton compost/fed.-fertilized plants which scored 97.6 and $130.5 \mathrm{~g}$ in the first and second seasons, respectively. Also, 5 ton compost/fed.-fertilized plants increased the fresh weight of herb as it scored 92.9 and $108.7 \mathrm{~g}$ in the first and second seasons, respectively. On contrary, the lowest herb weight/plant was gained by un-treated plants (control) as it registered 58.6 and $70.2 \mathrm{~g}$ in the first and second seasons, respectively. This trend was true in the three cuts in both seasons. As for the effect of bio-fertilizer, data in the same Table show that all applied doses of bio fertilizer statistically succeeded in increasing the fresh weight of moringa herb/plant as compared with un-fertilized plant in the two seasons. However, using the treatment of three doses showed to be the most effective one for inducing the highest fresh weight of herb as it scored 103 and $132.5 \mathrm{~g}$, followed by the treatment of two doses which recorded 95.9 and $116.2 \mathrm{~g} /$ plant in the first and second seasons, respectively. In addition, the treatment of one dose significantly increased the fresh weight of moringa herb as it gave 90.8 and 114 $\mathrm{g} /$ plant in the first and second seasons, respectively. On contrary, the lowest fresh weight of moringa herb was gained by those receive no bio fertilizer in the two seasons of this study. this trend was true in the three cuts in the two seasons.

Regarding the interaction effect between organic fertilizer and bio fertilizer data in Table (1) show that all resulted combinations between organic fertilizer and bio fertilizer increased the fresh weight of moringa herb / plant as compared with un-treated plants in the two seasons. Anyhow, the heaviest fresh weight of moringa herb was scored by those received the combined treatments between organic fertilizer at the high level ( 15 ton/fed.) 0 this trend was true in the first and third cut, while in the second cut the highest value of this parameter was obtained by the combined treatment between organic fertilizer at the medium level (10 ton / fed.) and bio fertilizer at the high dose in the two seasons of this study. On the reverse, the lowest value of this parameter was gained by un-fertilized plants in the two seasons.

\section{Herb dry weight/plant}

Data presented in Table (2) show that all studied treatments of organic fertilizer statistically increased herb dry weight of Moringa olifera plants of as compared with un-fertilized plants in both seasons. However, the heaviest dry weight of moringa herb was scored by 15 ton compost/fed.-fertilized plants, followed by 10ton compost/fed.-fertilized plants in the two seasons. Besides, 5 ton compost/fed.fertilized plants significantly increased the dry weight of herb in the two seasons. On the reverse, the lowest herb dry weight/plant was registered by untreated plants (control) in the two seasons. This trend was true in the three cuts in both seasons. Regarding the effect of bio-fertilizer, data in the same Table show that all added doses of bio fertilizer significantly succeeded in increasing the dry weight of moringa herb/plant as compared with un-fertilized plant in the two seasons. However, using the treatment of three doses is being the most effective one for giving the highest dry weight of herb, followed in descending order by those receive two doses in the two seasons. In addition, the treatment of one dose significantly increased the dry weight of moringa herb in both seasons. On the opposite, the lowest dry weight of moringa herb was gained by those receive no bio fertilizer in the two seasons of this study. This trend was true in the three cuts in the two seasons.

As for the interaction effect between organic fertilizer and bio fertilizer data in Table (1) indicate that all resulted combinations between the two studied factors increased the dry weight of moringa herb / plant as compared with un-treated plants in the two seasons. In general, the heaviest dr weight of moringa herb was scored by those received the combined treatments between organic fertilizer at the high level (15 ton/fed.). This trend was true in the first and third cut, while in the second cut the highest value of this parameter was obtained by the combined treatment between organic fertilizer at the medium level (10 ton / fed.) and bio fertilizer at the high dose in the two seasons of this study. On the reverse, the lowest value of this parameter was gained by un-fertilized plants in the two seasons. 
Table 1. Effect of bio and organic fertilization as well as their combination on Weight of a freash plant (gm) of Moringa olifera (L.) plant during 2017 and 2018 seasons.

First season 2017

\begin{tabular}{|c|c|c|c|c|c|c|c|c|c|c|c|c|c|c|c|}
\hline \multirow{2}{*}{$\begin{array}{l}\text { Parameters } \\
\text { Organic } \\
\end{array}$} & \multicolumn{3}{|c|}{ First cut } & \multicolumn{2}{|c|}{ Second cut } & \multicolumn{3}{|c|}{ Third cut } & \multirow[b]{2}{*}{$\begin{array}{c}\text { three } \\
\text { dose }\end{array}$} & \multirow[b]{2}{*}{ Mean } & \multirow[b]{2}{*}{ Zero } & \multirow[b]{2}{*}{$\begin{array}{c}\text { one } \\
\text { dose }\end{array}$} & \multirow[b]{2}{*}{$\begin{array}{l}\text { two } \\
\text { dose }\end{array}$} & \multirow[b]{2}{*}{$\begin{array}{l}\text { three } \\
\text { dose }\end{array}$} & \multirow[b]{2}{*}{ Mean } \\
\hline & Zero & $\begin{array}{c}\text { One } \\
\text { Dose }\end{array}$ & $\begin{array}{l}\text { Two } \\
\text { dose }\end{array}$ & $\begin{array}{c}\text { three } \\
\text { dose }\end{array}$ & Mean & Zero & $\begin{array}{c}\text { One } \\
\text { Dose }\end{array}$ & $\begin{array}{l}\text { Two } \\
\text { dose }\end{array}$ & & & & & & & \\
\hline Zero & 27 & 75.9 & 64.6 & 67 & 58.6 & 66 & 72 & 84 & 88 & 77.5 & 77 & 123 & 105 & 124 & 107.2 \\
\hline 5ton & 81.2 & 88.5 & 97 & 105 & 92.9 & 98 & 111.4 & 106 & 104 & 105.3 & 88 & 140 & 138 & 145 & 127.7 \\
\hline 10ton & 88.7 & 96 & 97 & 109 & 97.6 & 112 & 121 & 149 & 113 & 123.7 & 89 & 163 & 148 & 134 & 133.5 \\
\hline 15ton & 93 & 103 & 125 & 131 & 113 & 97 & 126 & 132 & 146 & 125.2 . & 99 & 156 & 168 & 174 & 149.2 \\
\hline Mean & 72.4. & 90.8 & .95 .9 & 103 & 90.5. & 93.2 & 107.6 & 117.7 & .112 .7 & 107.8 & 88.2 & 145.5 & 139.7 & 144.2 & 129.4 . \\
\hline 0.05 for bio & & & & & 4.5 & & & & & 5.3 & & & & & 6.4 \\
\hline \multirow{2}{*}{$\begin{array}{l}\text { L.S.D. at } 0.05 \text { for } \\
\text { organic } \\
\text { L.S.D. at } 0.05 \text { for bio } \times \\
\text { organic } \\
\end{array}$} & & & & & 4.5 & & & & & 5.3 & & & & & 6.4 \\
\hline & & & & & 9.02 & & & & & 10.6 & & & & & 12.8 \\
\hline \multicolumn{16}{|c|}{ Second season 2018} \\
\hline Zero & 63 & 67 & 71 & 80 & 70.2 & 39 & 65 & 70 & 86 & 65 & 72 & 92 & 98 & 111 & 93.2 \\
\hline 5ton & 96 & 112 & 100 & 127 & 108.7 & 70 & 123 & 135 & 138 & 116.5 & 154 & 186 & 192 & 208 & 185 \\
\hline 10ton & 107 & 126 & 138 & 151 & 130.5 & 80 & 112 & 149 & 127 & 117 & 163 & 211 & 221 & 216 & .202 .7 \\
\hline 15ton & 126 & 151 & 156 & 172 & 151.2 & 112 & 168 & 148 & 153 & 145.2 & 188 & 193 & 208 & 221 & 238.8 . \\
\hline Mean & .98 & 114 & 116.2 & .132 .5 & 115.1 & 75.2 & 117 & 125.5 & 126 & 110.9 & 144.2 & 170.2 & 179.7 & .189 & 170.7 \\
\hline 0.05 for bio & & & & & 5.7 & & & & & 5.5 & & & & & 8.5 \\
\hline $\begin{array}{l}\text { L.S.D. at } 0.05 \text { for } \\
\text { organic }\end{array}$ & & & & & 5.7 & & & & & 5.5 & & & & & 8.5 \\
\hline $\begin{array}{l}\text { L.S.D. at } 0.05 \text { for bio } \times \\
\text { organic }\end{array}$ & & & & & 11.4 & & & & & 11 & & & & & 17 \\
\hline
\end{tabular}


Effect 2. Table of bio and organic fertilization as well as their combination on dry wight of plant (gm) of Moringa olifera (L.) plant during 2017 and 2018 seasons.

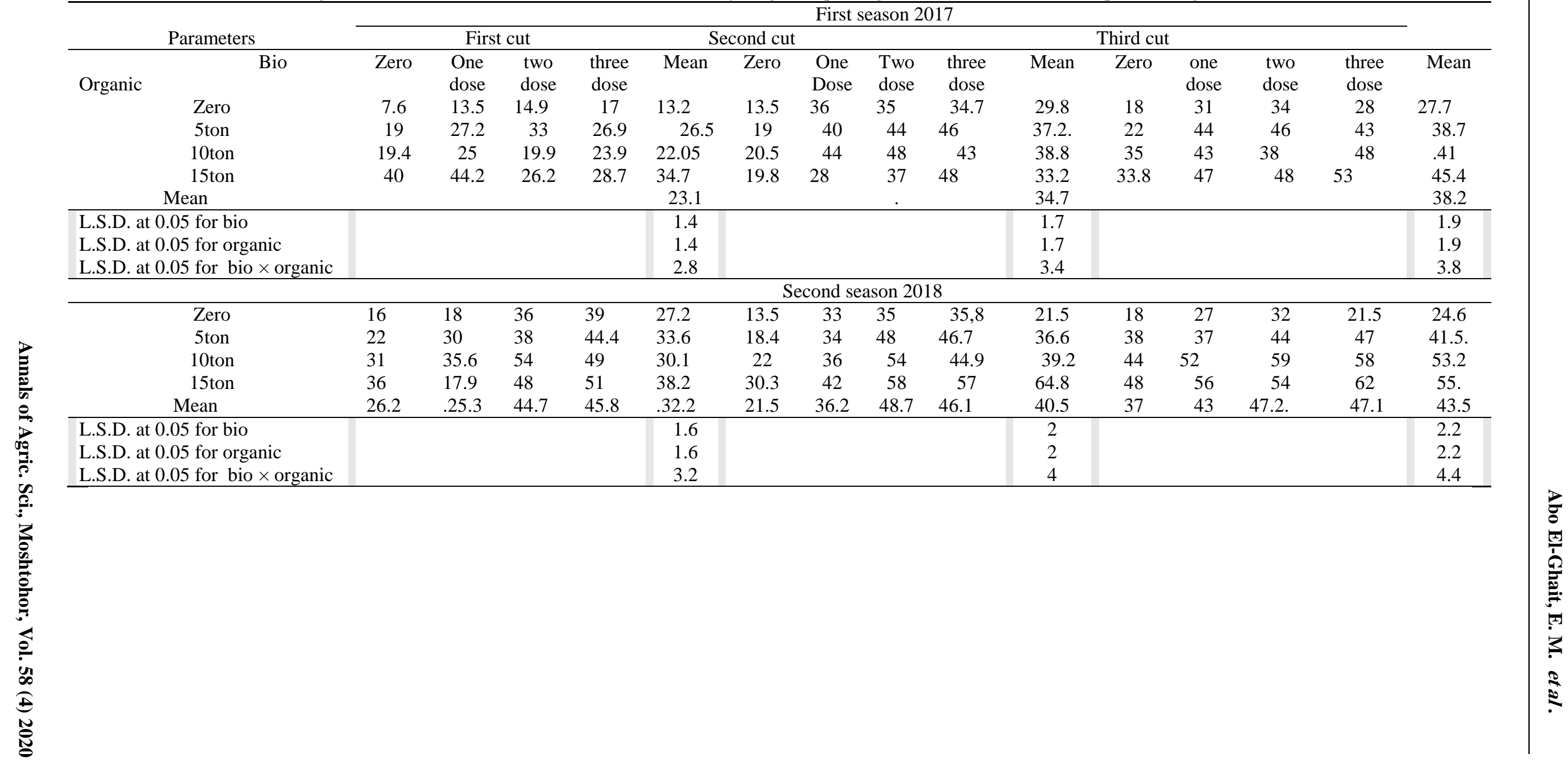




\section{3- On plant height (cm):}

Data in Table (3) cleared that all examined organic fertilizer concentrations increased the plant height of Moringa olifera plant when compared with control plants in both seasons. On the other side, the increase in plant height of Moringa plants is linearly increased with the increment of organic fertilizer concentration, so the tallest plants was recorded by 15 ton compost/fed-treated plants as it scored 83.5 and $77.5 \mathrm{~cm}$, followed in descending order by 10 ton compost/fed-treated plants which recorded 73.5 and $71.5 \mathrm{~cm}$ in the first and second seasons, respectively. The differences between the abovementioned two treatments were significant in both seasons. Besides, compost at 5 ton/fed. gave highly increments in this parameter in the two seasons. Respecting the effect of bio fertilizer, data in Table (3) reveal that the highest values of plant height was gained by using the high dose (three doses) which scored 86 and 82.5 $\mathrm{cm}$, followed in descending order by the medium dose as it recorded 78.5 and $71 \mathrm{~cm}$ in the first and second seasons, respectively. Furthermore, bio fertilizer at the low dose gave high increments in this concern in the two seasons. On the opposite, the lowest values of this parameter were gained by using un-fertilized plants in the two seasons. Referring to the interaction effect between organic fertilizer and bio fertilizer data in Table (3) show that the combination of bio fertilizer at the high dose significantly induced the greatest values of plant height, particularly those treated with organic fertilizer at the highest concentration in the two seasons. On the contrast, the lowest values were scored by the un-fertilized as it gave 40 and $48 \mathrm{~cm}$ in the first and second seasons, respectively. The remained treatments occupied an intermediate position between the aforementioned treatments in the two seasons.

\section{4- On branches number / plant:}

The data obtained in Table (7) on branches number / plants show that all tested concentrations of organic fertilizer statistically increased the values of branches number / plant of Moringa olifera plants in both seasons. However, the highest values were gained by 15 ton compost/fed.-treated plants in the first cut, 10 ton compost/fed.-treated plants in the second and third cut. This trend was true only in the first season, while in the second one 10 ton compost/fed.-treated plants, showed its superiority in this concern for the first and second cut, while the third cut 15 ton compost / fed. Was superior for inducing the tallest plant.

With studying the effect of bio fertilizer data in Table (4) clear that the highest branches number / plants was gained by bio fertilizer at the medium dose, followed by the high dose in the two seasons for the fist cut, while in the second and third cut bio fertilizer at the high dose is being to be the most effective one for inducing the greatest number of branches / plant in the two seasons. On the reverse, the lowest values of this parameter were obtained by un-fertilized plants in the two seasons.

Respecting the interaction effect between organic fertilizer and bio fertilizer, data in the same Table refer that the greatest values of branches number / seedling were gained by the combinations of organic and bio fertilizers at the medium and high levels in the two seasons.

\section{5- On leaves number/plants.}

The data outlined in Table (5) on leaves number / plants reveal that all studied concentrations of organic fertilizer significantly increased the values of leaves number / plant of Moringa olifera plants in both seasons. However, the highest values were gained by 15 ton compost/fed.-treated plants in the two seasons, in the three cuts, except the first cut in the second season, as 10 ton compost/fed. Showed its superiority in this concrn. In addition, 10 ton compost/fed.-treated plants induced high significant increments in this concern in the two seasons of this study.

As for the effect of bio fertilizer data in Table (5) clear that the highest leaves number / plants was gained by bio fertilizer at the high dose, followed by the medium dose as an average of the two seasons. On the reverse, the lowest values of this parameter were obtained by un-fertilized plants in the two seasons. Respecting the interaction effect between organic fertilizer and bio fertilizer, data in the same Table refer that the greatest values of leaves number / seedling were scored by the combinations of organic and bio fertilizers at the high and medium levels in the two seasons.

It is preferable from the previous results that treating Moringa olifera plants with the combined treatment between bio-fertilizers at three doses and organic fertilizer at 15 ton / fed for enhancing growth and productivity of this plant. Therefore, the present study strongly admit the use of such treatments to provide good and high exportation characteristics due to its safety role on human health. 
Table, 3. Effect of bio and organic fertilization as well as their combination on plant height(cm) of Moringa olifera (L.) plant during 2017 and 2018 seasons.

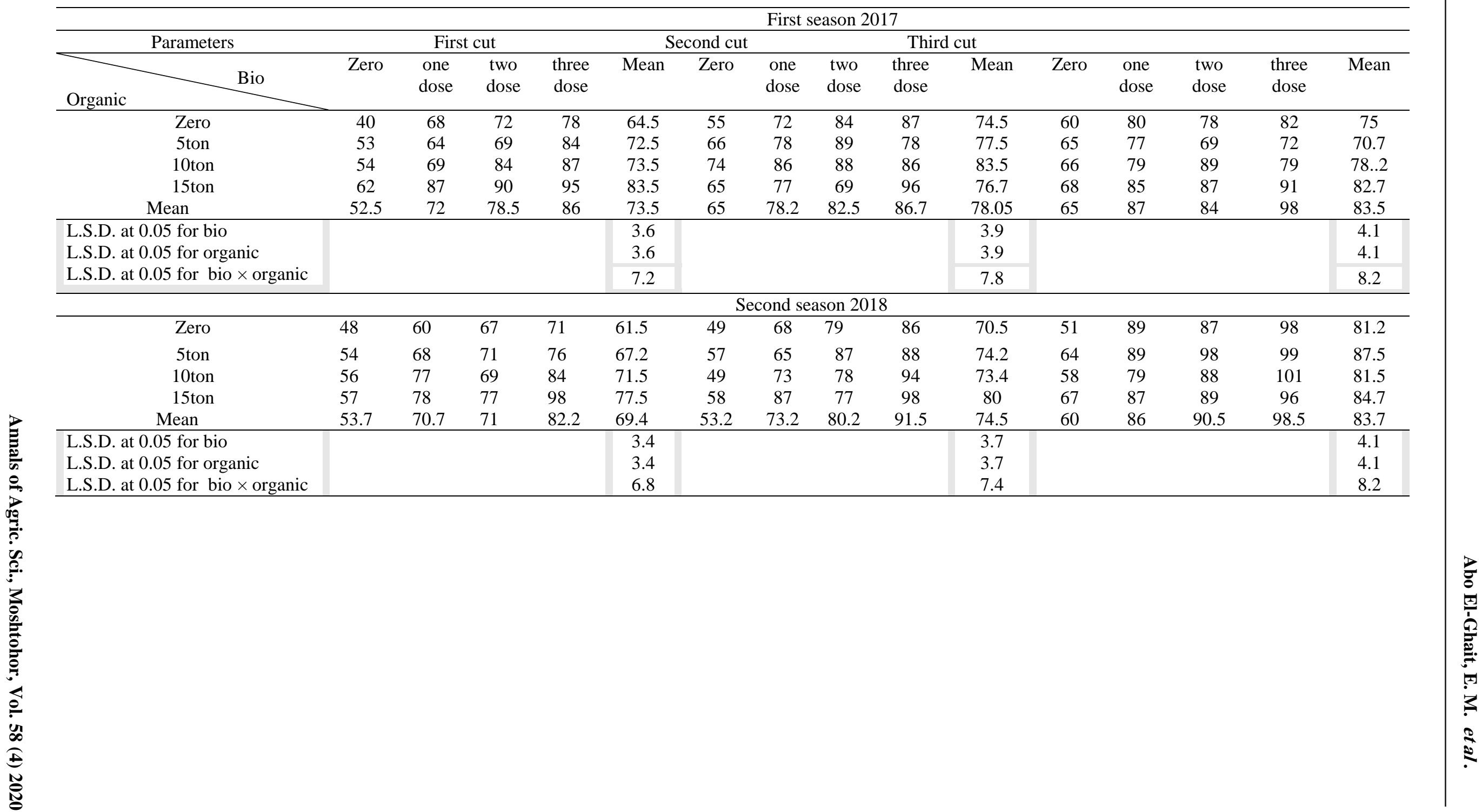


Table, 4. Effect of bio and organic fertilization as well as their combination on branches number of Moringa olifera (L.) plant during 2017 and 2018 seasons.

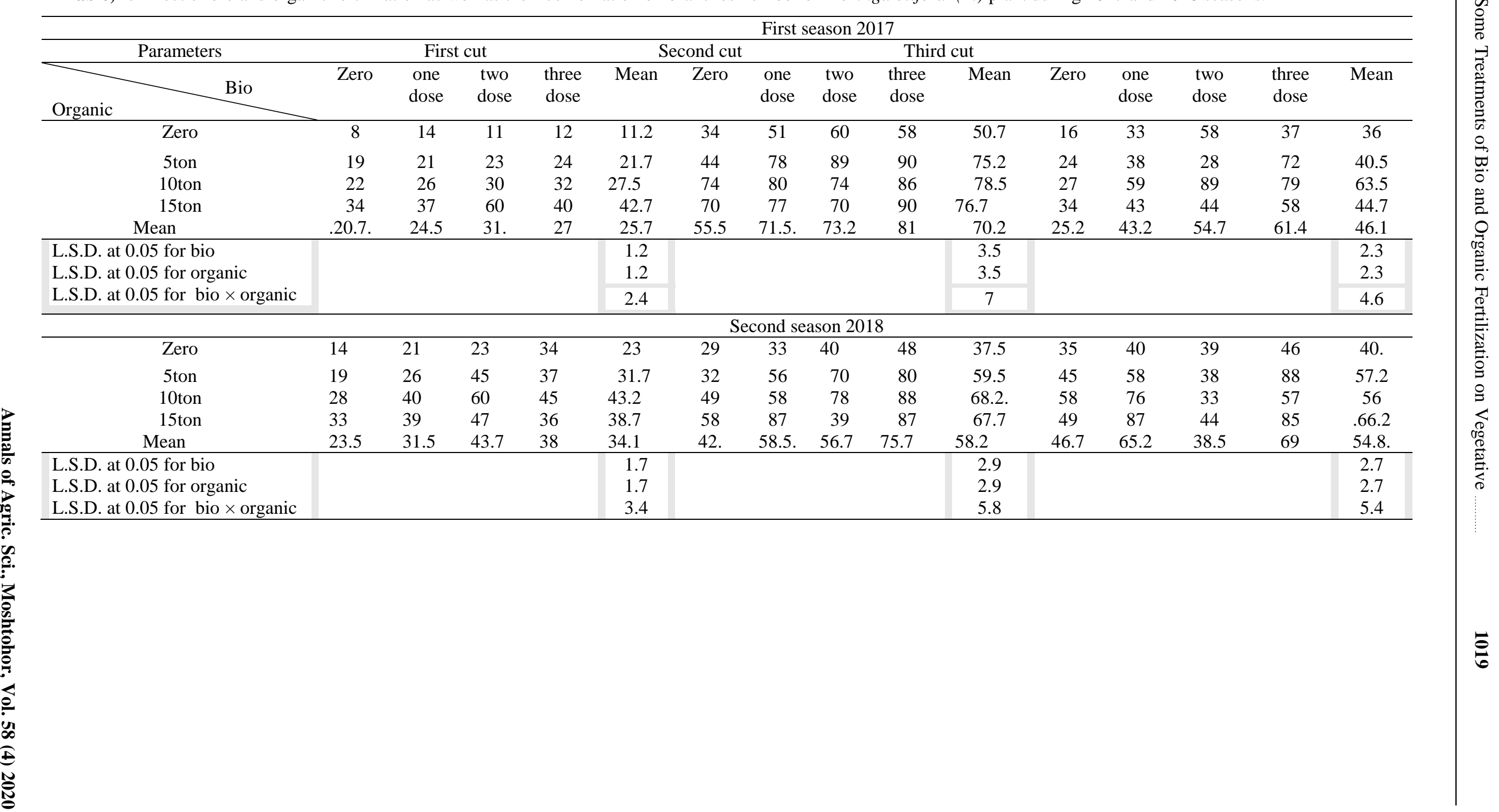


Table 5. Effect Table of bio and organic fertilization as well as their combination on leaves number of Moringa olifera (L.) plant during 2017 and 2018 seasons.

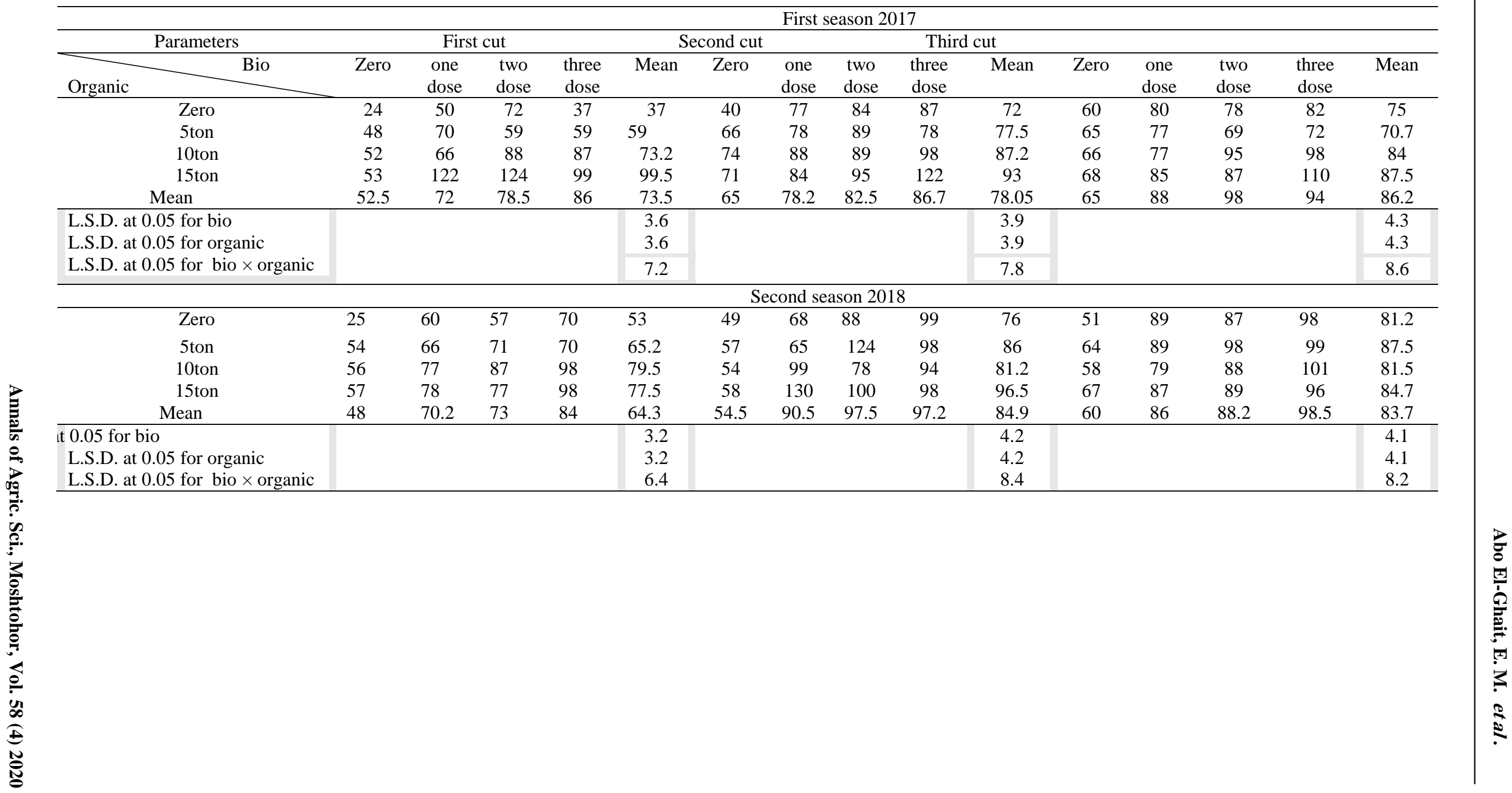




\section{Referencies}

Abd-Allah, Wafaa H. A. E. (2012): Effect of sowing dates and fertilization treatments on growth and production of Indian fennel compared with varieties of fennel plants grown in Egypt under Sinai conditions. Ph.D. Thesis, Fac. Agric., Benha Univ., Egypt.

Abd El-Aleem, W.; Hendawy, S. F.; Hamed, E. S. and Toaima, W. I. M. (2017): Effect of planting dates, organic fertilization and foliar spray of algae extract on productivity of Dutch fennel plants under Sinai conditions. Journal of Medicinal Plants Studies, 5 (3): 327-334.

Abd El-Azim, W. M.; Rania, M.R. and Badawy, M.Y.M. (2017): Effect of bio-fertilization and different licorice extracts on growth and productivity of Foeniculum vulgare Mill. Plant Middle East J., 6: 1-12.

Abdelkader, M. A.; Gendy, A. S.; Bardisi, I. A. and Elakkad, H. A. (2018): The impact of NPK fertilization level and Lithovit concentration on productivity and active ingredients of Coriandrum sativum plants. Sciences, 8 (3): 827 836.

Abdel Wahab, M. M. and Hassan, A. Z. A. (2013): Response of fennel plants to organic biofertilizer in replacement of chemical fertilization. Top Class Journal of Agric. Res., 1 (3): 29-35.

Abdel Wahab, M. M.; El-Attar, A. B. and Shehata, S. A. (2016): Boosting fennel plant yield and components using combination of manure, compost and biofertilizers. Arabian Journal of Medicinal and Aromatic Plants, 2 (1): 37-50.

Abou-Aly, H. E. and Gomaa, A. O. (2002): Influence of combined inoculation with diazotrophs and phosphate solubilizers on growth, yield and volatile oils content of coriander plants (Coriandrum sativum, L.). Bulletin-Faculty of Agriculture University of Cairo, 53 (1): 93-114.

Abou El-Ghait, E.M.; Gomaa, A.O.; Youssef, A.S.M.; Atiea, E.M. and Abd-Allah, W.H. (2012): Effect of sowing dates, bio, organic and chemical fertilization treatments on growth and production of Indian fennel under north Sinai conditions. Bull. Fac., Cairo Univ., 63: 52-68.

Alipoor, F.; Alizadeh, K. and Arshad, M. (2016): The impact of fertilization on morphological characteristics of fennel (Foeniculum vulgare Mill.). Stem Cell, 7 (2): 1-8.

Alireza, D. (2012): Effect of chemicals and biofertilizers on yield, growth parameters and essential oil contents of fennel (Foeniculum vulgare Miller). Journal of Medicinal Plants and By-products, 2: 101-105.

Al-Qadasi, A.S. (2004): Effect of biofertilization on Ocimum basilicum, L. plant. M.Sc. Thesis, Fac. Agric., Cairo Univ., Egypt.
Amran, K.A.A. (2013): Physiological studies on Pelargonium graveolens L plant. Ph.D. Thesis, Fac. of Agric., Moshtohor, Benha. Univ., Egypt.

A.O.A.C. (1970): Official Methods of Analysis of Association of Official Agriculture Chemists. Washington, D.C., $10^{\text {th }}$ Ed.

Ehsanipour, A.; Razmjoo, J. and Zeinali, H. (2012): Effect of nitrogen rates on yield and quality of fennel (Foeniculum vulgare Mill.) accessions. Industrial Crops and Products, 35 (1): 121-125.

El-Bassiony, A. M.; Fawzy, Z. F.; Zaki, M. F. and El-Nemr, M. A. (2014): Increasing productivity of two sweet fennel cultivars by foliar spraying of some bio and organic compounds. Middle East J. Appl. Sci, 4: 794-801.

El-Merich, C.; De-Zamarozy, M.; Arsene, F.; Pereg, T.; Paquellin, A. and Kaminski, A. (1997): Regulation of NIF gene expression and nitrogen metabolism in Azospirillum. Soil Biol. Biochem., 29 (5-6): 847-852.

El-Shora, S.E. (2009): Physiological studies on Mentha spp. (fertilization-post harvest treatments). M.Sc. Thesis, Fac. Agric., Moshtohor, Benha Univ.

El-Tohamy, W. A.; El-Abagy, H. M. and ElGreadly, N. H. M. (2008): Studies on the effect of putrescine, yeast and vitamin $\mathrm{C}$ on growth, yield and physiological responses of eggplant (Solanum melongena L.) under sandy soil conditions. Aust. J. Basic Appl. Sci, 2 (2): 296300 .

Gomaa, A. O. and Youssef, A. S. M. (2007a): Biofertilizers as a partial alternative to chemical NPK fertilization and its influence on the productivity of fennel plants (Foeniculum vulgare, Miller). The third Conference of Sustainable Agricultural Development, Faculty of Agriculture, Fayoum University, 327-352.

Gomaa, A.O. and Youssef, A. S. M. (2008): Efficiency of bio and chemical fertilization in presence of humic acid on growth performance of caraway. Proe Scientific Conference of Agric. and Biol. Res. Division under the theme. May 56, Hort. Dept., Fac. Agric., Moshtohor, Benha University, Egypt.

Gomaa, A.O. and Youssef, A.S.M. (2007b): Influence of chemical, organic and bio-fertilizer application on growth and productivity of lovage plant (Levisticum officinale, Koch). Egypt J. of Appl. Sci., 22 (IIB): 492-520.

Gomaa, A.O.; Youssef, A. S. M.; Mohamed, Y.F.Y. and AbdAllah, M.S.A. (2018): Effect of some fertilization treatments on growth, productivity and chemical constituents of roselle (Hibiscus Sabdariffa L.) plants. Scientific J. Flowers \& Ornamental Plants, 5 (2): 171-193.

Hegde, D.M.; Dwivedi, B.S. and Sudhakara Babu, S.S. (1999): Biofertilizers for cereal production in India. A review. Ind.J. Agric.Res., 69(2): 73-83. 
Hellal, F.A.; Mahfouz, S.A. and Hassan, F.A.S. (2011): Partial substitution of mineral nitrogen fertilizer by biofertilizer on (Anethum graveolens L.) plant. Agric. Biol. J. N. Am., 2 (4): 652-660.

Kiani, S.; Siadat, S. A.; Telavat, M. R. M.; Mashhadi, A. R. A. and Sare, M. (2014): Effect of nitrogen fertilizer application on forage yield and quality of barley (Hordeum vulgare L.) and fennel (Foeniculum vulgare L.) intercropping Iranian J. of Crop Sci., 16 (2): 77-90.

Koppula, S. and Kumar, H. (2013): Foeniculum vulgare Mill (Umbelliferae) attenuates stress and improves memory in wister rats, Tropical Journal of Pharmaceutical Research 12 (4): 553-558.

Mady, M. A. and Youssef, A. S. M. (2014): Influence of some fertilizers and boron foliar spray on improving growth and oil productivity of dragonhead (Dracocephalum moldavica L.) Plant. J. Plant Production, 5 (4): 587-613.

Mahdi, S.S.; Hassan, G.I.; Samoon, S.A.; Rather, H.A.; Dar, S.A. and Zehra, B. (2010): Biofertilizers in organic agriculture. J. Phytol., 2 (10): 42-54.

Mahfouz, S.A. and Sharaf-Eldin, M.A. (2007): Effect of mineral vs. bio-fertilizer on growth, yield and essential oil content of fennel (Foeniculum vulgare Mill). International Agrophysics, 21 (4): 361-366.

Mahmoud, A.W.M.; EL-Attar, A.B. and Mahmoud, A.A. (2017): Economic evaluation of nano and organic fertilizers as an alternative source to chemical fertilizers on Carum carvi L. plant yield and components. Agriculture (Pol'nohospodárstvo), 63 (1): 33-49.

Mishra, B.K.; Lal, G.; Sharma, Y.K.; Kant, K.; Saxena, S.N. and Dubey, P.N. (2019): Effect of microbial inoculants on cumin (Cuminum cyminum Linn.) growth and yield. International J. Seed Spices, 9 (1): 53-56.

Moghith, W. M. A. (2016): Effect of organic and biofertilization on the growth, production and chemical constituents of Origanum vulgare L. plants. M. Sc. Thesis, Fac. Agric., Tanat Univ.

Moosavi, G.; Seghatoleslami, M.; Ebrahimi, A.; Fazeli, M. and Jouyban, Z. (2013): The effect of nitrogen rate and plant density on morphological traits and essential oil yield of coriander. Journal of Ornamental and Horticultural Plants, 3 (2): 95-103.

Nowak, J. and Szemplinski, W. (2011): Effect of nitrogen and boron fertilization on the morphometric features and yield of coriander (Coriandrum sativum L.). Acta Sci. Pol., Agricultura, 10 (3): 111-118.

Osman, Y. A. H. (2000): Possibility of production of Coriander (Coriandrum sativum L.) under Sinai conditions (Doctoral dissertation, Ph.D. Thesis, Faculty of Agriculture Cairo University).

Osman, Y. A. H., (2009): Comparative study of some agricultural treatments effects on plant growth, yield and chemical constituents of some fennel varieties under Sinai conditions. Res. J. Agric. and Biolog. Sci., 5 (4): 541-554.

Ramadan, A. M. and Ragab, S. T. (2015): Improving growth and yield of caraway (Carum carvi L.,) plants by decapitation and/or active dry yeast application. Int. J. Curr. Microbiol. App. Sci, 4 (9): 47-60.

Rashed, N.M.; Mensy, F.A. and El-Mahrouk, E.M. (2002): Effect of bio-organic and chemical fertilization on dill, coriander and parsley. J. Agric. Sci. Mansoura Univ., 27 (12): 8337-8345.

Rather, M.A.; Dar, B.A. and Sofi, S.N. (2012): Foeniculum vulgare, A comprehensive review of its traditional use, phytochemistry, pharmacology, and safety. Arabian Journal of Chemistry 2: 1-10.

Saric, M.; Katrori, R.; Curic, R.; Cupina, T. and Gric, I. (1967): Chlorophyll Determination. Univerzitet U. Noveon Sadu praktikum iz fiziologize Biljaka-beograd. Hauena Anjiga, 215.

Soliman, S.G.I.; Harridy, I.M.A. and Ismail, E.G. (2009): Response of French basil plants (Ocimum bacilicum) to nitrogen fixing bacteria. J. Agric. Sci. Mansoura Univ., 34 (5): 5137-5150.

Waskela, P.; Naruka, I. S. and Shaktawat, R. P. S. (2017): Effect of row spacing and level of NPK on growth and yield of fennel (Foeniculum vulgare). Journal of Krishi Vigyan, 6 (1): 78-82.

Youssef, A.S.M.; Mady, M.A. and Ali, M.M.E. (2014): Partial substitution of chemical fertilization of roselle plant (Hibiscus Sabdariffa L.) by organic fertilization in presence of ascorbic acid. J. Plant Production, Mansoura Univ., 5 (3): 475-503.

Zahir, A.Z.; Arshad, M.; Azam, M. and Hussein, A. (1997): Effect of an auxin precursor tryptophan and Azotobacter inoculation on yield and chemical composition of potato under fertilized conditions. J. of Plant Nutrition, 20: 745-0752.

Zaid, H.A. (1992): Effect of Rhizobacteria and nitrogen fertilization on the yield of barley. J. Agric. Sci. Mansoura Uni., 17: 3981-3986.

Zand, A.; Darzi, M.T. and Hadi, M.R.H.S. (2013): Effects of phosphate solubilizing microorganisms and plant density on seed yield and essential oil content of anise (Pimpinella anisum). MiddleEast Journal of Scientific Research, 14 (7): 940946.

Zapater, R.M.; Graham, P.H.; Harris, S.C. (1982): Effect of Azotobacter inoculation and nitrogen fertilization on the yield of seed potatoes in the coastal area of Peru. Biological Nitrogen Fixation Technology for Tropical Agriculture, 533-535.

Zayed, M.S. (2012): Improvement of growth and nutritional quality of Moringa oleifera using different bio-fertilizers. Annals of Agricultural Science (Cairo), 57 (1): 39-49. 